Georgia State University

ScholarWorks @ Georgia State University

$11-16-2020$

\title{
Dynamics of International Giving: How Heuristics Shape Individual Donor Preferences
}

Suparna Chaudhry

Lewis \& Clark College, schaudhry@lclark.edu

Andrew Heiss

Georgia State University, aheiss@gsu.edu

Follow this and additional works at: https://scholarworks.gsu.edu/pmap_facpubs

Part of the Public Affairs, Public Policy and Public Administration Commons

\section{Recommended Citation}

Chaudhry S, Heiss A. Dynamics of International Giving: How Heuristics Shape Individual Donor Preferences. Nonprofit and Voluntary Sector Quarterly. November 2020. doi:10.1177/0899764020971045

This Article is brought to you for free and open access by the Department of Public Management and Policy at ScholarWorks@ Georgia State University. It has been accepted for inclusion in PMAP Publications by an authorized administrator of ScholarWorks @ Georgia State University. For more information, please contact scholarworks@gsu.edu. 


\title{
Dynamics of International Giving: How Heuristics Shape Individual Donor Preferences"
}

\author{
Suparna Chaudhry \\ Lewis \& Clark College \\ schaudhry@lclark.edu

\section{Andrew Heiss} \\ Georgia State University \\ aheiss@gsu.edu
}

\begin{abstract}
State restrictions on non-governmental organizations (NGOs) have become increasingly pervasive across the globe. While this crackdown has been shown to have a negative impact on public funding flows, we know little about how it impacts private philanthropy. How does information about crackdown abroad, as well as organizational attributes of nonprofits affect individual donors' willingness to donate internationally? Using a survey experiment, we find that learning about repressive NGO environments increases generosity in that already-likely donors are willing to donate substantially more to legally besieged nonprofits. This generosity persists when mediated by two organizational-level heuristics: NGO issue areas and main funding sources. We discuss the implications of our results on how nonprofits can use different framing appeals to increase fundraising at a time when traditional public donor funding to such organizations is decreasing.
\end{abstract}

\footnotetext{
"We thank Mark Buntaine, Michael DeCrescenzo, Jeffrey Friedman, Thomas Leeper, and Tristan Mahr for their helpful comments and input, as well as the anonymous reviewers at Nonprofit and Voluntary Sector Quarterly (NVSQ) for their excellent feedback. We also thank Samantha Camilletti and Joshua Dutro for their excellent research assistance. This experiment received approval by the human subjects research committees at both Christopher Newport University (018.042) and Brigham Young University (E18104). We preregistered our hypotheses and research design at the Open Science Framework, and our preregistration protocol is available at https://osf.io/dx973/.
} 
Over the last three decades, governments across the world have sought to limit the work of nonprofits and nongovernmental organizations (NGOs)-a phenomenon known as "closing civic space" (Carothers, 2015; Dupuy et al., 2016). Repressive governments have enacted laws creating barriers to advocacy and funding for a variety of NGOs. The adverse effects of these laws are particularly felt in countries with weak institutions and poor governance. International donors directing aid to these countries typically seek out NGOs to implement their projects, as direct aid transfers to recipient governments pose the risk of misuse and bureaucratic inefficiency (Dietrich, 2013). However, official aid flows to NGOs have decreased considerably in countries that repress NGOs (Brechenmacher, 2017; Chaudhry \& Heiss, 2018; Dupuy \& Prakash, 2018). While we know there has been a negative impact on funding from official donors, we know relatively little about how this crackdown affects private donors, in particular how it influences individual donors' willingness to donate internationally.

Charitable giving to nonprofits working in international affairs has steadily increased over the past two decades. ${ }^{1}$ From 2014-2016, giving to international affairsfocused issues increased by $14.1 \%$ (IUPUI Lilly Family School of Philanthropy, 2017). This amount is not insignificant-by 2016, total private giving to nonprofits working in international affairs had increased to $\$ 22.03$ billion (Giving USA, 2017). Most notably, a large portion of this growth was driven by individuals making small-scale donations. In 2017 , individuals gave $\$ 286.7$ billion, or approximately $70 \%$ of total giving to international affairs. This further increased to $\$ 427.71$ billion in $2018,85.7 \%$ of which was through individuals (Giving USA, 2019). While much is known about individuals' motivations for giving locally (Bekkers \& Wiepking, 2011), much less is known about motivations to give internationally. These large amounts show the urgency of understanding this phenomenon. What factors affect individual donor preferences on giving to international causes? How does information about repressive NGO environments abroad affect donors' willingness to donate internationally, and how does knowledge of legal crackdown interact with other organizational attributes?

Given information asymmetry and time constraints, individual donors often use heuristics to simply their decision-making (Croson \& Shang, 2011; Tremblay-Boire $\&$ Prakash, 2017). Framing, or the process through which actors present information to influence perceptions of behavior, is particularly important in this regard (Chong \& Druckman, 2007), as NGOs' appeals for donations are framed by structural and organizational characteristics. We use a survey experiment fielded in

1. According to Giving USA, the category of "international affairs" includes nonprofits working in international development, international relief services, disaster relief, international human rights, international peace and security, foreign policy research and analysis, and international exchange programs. 
the U.S. to assess how different structural and organizational-level heuristics affect donor preferences. We find that learning about repressive NGO environments increases generosity and that already-likely donors are willing to donate substantially more to legally restricted nonprofits.

This generosity persists when mediated by two important organization-level heuristics: issue area and funding source. Learning about crackdown increases individuals' willingness to donate to privately funded nonprofits. This may be because the survival of the NGO appears to be in question and the donor's assessment might be that their donation actually makes a difference. These results are particularly substantive for privately-funded human rights NGOs facing crackdown, with donors showing an increased willingness to not just donate to them, but also to donate more to them. While not unsurprising, this does suggest that private donors to human rights NGOs likely know that their work is always challenging to host governments, and that such organizations need greater support when facing hostile environments.

Our study makes a significant contribution to research on individual giving and indicates the promise and limits of different framing appeals on individual donor preferences. While factors shaping individual giving to domestic causes have been thoroughly explored in existing literature, the dynamics of international giving are less explored. ${ }^{2}$ Understanding the latter is important as philanthropy to international causes can be harder to motivate because the number of recipients is larger and further removed from the donor (Casale \& Baumann, 2015, p. 100).

Second, most nonprofits working internationally have traditionally relied on government and foundation funding. In the era of closing civic space, NGOs may need to reframe and tailor their fundraising strategies to individual donors. However, we lack systematic studies of which frames may be effective when making appeals to donors considering international philanthropy. Our study examines the impact of political frames such as regulatory crackdown, and how this frame interacts with organizational attributes to change donor preferences. Accordingly, our results can help international nonprofits frame their appeals for funding, especially when facing restricted legal space abroad.

Below, we summarize existing research on the determinants of giving to NGOs and lay out our expectations regarding how crackdowns and NGO organizational attributes individuals' philanthropic preferences. We then describe our survey experiment and present the results. We conclude with implications for NGOs working in repressive countries and lay out questions ripe for future research.

2. For exceptions, see Micklewright and Schnepf (2009) on the UK, Rajan et al. (2009) on Canada, Wiepking and Bekkers (2010) on the Netherlands, and Casale and Baumann (2015) on the USA. 


\section{Philanthropy towards international NGOs}

Thousands of international NGOs (INGOs) in the Global South receive funds from a variety of public and private sources each year. ${ }^{3}$ Though we focus on private funding in this article, it is essential to differentiate between the two sources. Public aid, or more traditional donor aid, channels funds from official aid agencies towards nonprofits through a variety of bilateral and multilateral institutions. Private funds come from foundations, corporations, and individuals. We are specifically interested in individual-level determinants of private international philanthropy.

Nonprofits working internationally typically rely heavily on official aid from government sources. In 2018, for instance, humanitarian INGOs received $81 \%$ of their total funding from governments and EU institutions (Development Initiatives, 2020). However, private giving to nonprofits working in international affairs has increased consistently over the past decade. Donations from individuals have far outstripped foundation and corporate giving-in 2018, individual donations amounted to $\$ 292.09$ billion, compared to $\$ 75.86$ billion from foundations and $\$ 20.05$ billion by corporations. While foundations are often seen as the primary funders of international nonprofits, they accounted for only $18 \%$ of all charitable giving in 2018-and grants from the Bill and Melinda Gates Foundation accounted for more than half of all foundation giving (Giving USA, 2019). Moreover, while government, foundation, and corporate funding is often earmarked for specific purposes, private donations are typically unrestricted funds. ${ }^{4}$ Individual donors thus play an incredibly important-and underexplored-role in funding international NGOs.

Given these substantive amounts, understanding individual motivations to donate internationally is important as individual donor preferences may not necessarily mirror the preferences of official aid agencies. While there is evidence that citizens generally support the goals of aid agencies (Milner \& Tingley, 2010), surveys show that the American public is notoriously misinformed about U.S. foreign aid (Norris, 2019). Further, both foreign aid and democracy aid are often considered unresponsive to political developments in recipient countries (Carothers, 2015) and public aid decisions-especially regarding final recipients and amounts-are not easily accessible. There is also heterogeneity in how donor governments allocate funds. For instance, unlike established donors such as the United States and other Organisation for Economic Cooperation and Development (OECD) countries,

3. We use the terms nonprofit organizations and NGOs interchangeably. We consider international NGOs to be nongovernmental organizations with members from two or more countries and that work in countries outside of their home country.

4. We thank an anonymous reviewer for this insight. 
emerging donor governments tend to demand fewer human rights, governance, or environmental preconditions (Fengler \& Kharas, 2010).

Recent experimental evidence also finds little support for the idea that individual donor behavior mimics that of official donors. Desai and Kharas (2018) find that unlike official donors who tend to channel funds to countries with better institutional quality or to reward governmental performance (Bermeo, 2011; Dietrich \& Wright, 2015), individual donors do not use the same performance-based metrics. Rather, individuals are more inclined to donate to NGOs in countries experiencing a humanitarian crisis-in particular, crises following natural disasters. Desai and Kharas (2018) conclude that compared to donor agencies, "private donors respond to different project and country characteristics" (p. 517). International philanthropy by individuals should therefore be investigated on its own terms.

Looking at different funding flows, it is also notable that private funding towards nonprofits working internationally appears to not be as adversely impacted as public funding flows in the face of the global crackdown on NGOs. While anti-NGO restrictions have reduced official aid to repressive countries (Dupuy \& Prakash, 2018), private foundations have continued to channel funds to countries with unfriendly legal environments (Foundation Center, 2018). Accordingly, it is imperative to understand whether individual donors mirror the trajectory of foundations when giving internationally, especially to organizations facing legal crackdown abroad.

\section{Key drivers of individual-level philanthropy}

Substantial research on charitable giving has looked at the motivations of individual donors (Bekkers \& Wiepking, 2011; Wiepking, 2010). However, research on individual donor behavior has overwhelmingly examined giving to organizations working locally, rather than internationally. This literature has primarily focused on the importance of three main factors, especially when considering international philanthropy: (1) the role of social and associational capital, (2) the role of individual experiences such as higher education and levels of religiosity, and (3) third-party certifications.

Prior research has found that those who participate in a variety of associations and build social capital are more likely to make charitable donations as well as make larger donations (Hossain \& Lamb, 2017). An individual's social network also plays an important in deciding to donate. Looking at relational configurations in social networks, Herzog and Yang (2018) find that having both a giver and a solicitor in one's social network increased the likelihood of that individual's charitable giving.

Individual experiences such as access to higher education and increased religiosity can also influence giving (Wiepking \& Bekkers, 2010). Higher education fosters pro-social motivations and brings people into social networks that entail a 
higher level of solicitation (Bekkers \& Wiepking, 2011). Education also increases abstract thinking (Wiepking \& Maas, 2009, p. 1978), which is important for donating to distant international relief organizations than donating to local, more visible nonprofits (Micklewright \& Schnepf, 2009). Overall, individuals with higher levels of income, education, and greater religious proclivities have been shown to not only be more likely to give internationally, but also to give higher amounts (Casale \& Baumann, 2015; Rajan et al., 2009).

Finally, information about organizational characteristics and third-party certifications can also impact levels of individual philanthropy, though results are mixed. Existing research shows that information on the efficiency of NGOs merely steers rather than encourages or discourages overall donations (Ryazanov \& Christenfeld, 2018). The effects of changes in charity watchdog ratings and nonprofit accountability systems on individual donors is also mixed, showing that donors do not have the time to research charities thoroughly (Bekkers, 2010) and that ratings by charity watchdogs do not really affect donor support for these nonprofits (Szper \& Prakash, 2011).

Even though these above factors affect individuals' motivations to donate internationally, extant literature on international giving focuses on donating during crises and emergencies. However, as Micklewright and Schnepf (2009) point out, motivations for donating to ongoing international causes differ from donating money to natural disasters or emergency international causes. Under ordinary circumstances, "donors are more likely to donate to a charity operating locally than to a charity providing identical service abroad" (Tremblay-Boire \& Prakash, 2017, p. 644). However, we lack adequate data and theory regarding international philanthropy. Most research on individual donors to international causes has been restricted to elite, high net-worth donors-those with more than \$200,000 in annual income or $\$ 1$ million in assets (US Trust, 2014). However, given the increasing funds channeled by individuals to international nonprofits, it is crucial to understand what motivates these donors to donate.

Individuals rely on heuristics that differ from the benchmarks used by large governmental agencies and private foundations. These signals, we argue, can be even more important in giving to international causes. In theory, donors should scrutinize each aspect of an NGO's organizational structure and programmatic performance prior to donation, but this rarely happens in practice (Tremblay-Boire \& Prakash, 2017). Instead, donors respond to a host of heuristics when deciding whether to donate to an NGO, since seeking complete information about an organization is costly and time-consuming. These heuristics are commonly rooted in donor perceptions of organizational characteristics-donors make cursory judgments about an organization's issue area, mission, vision, and values, and seek out supplementary information from friends, family, and acquaintances (Sloan, 2009; 
Szper \& Prakash, 2011). Nonprofits fundraising internationally may therefore rely on framing to control perceptions. Below, we theorize the effect of different frames surrounding a country's legal environment and nonprofit organizational characteristics on individual donor preferences.

\section{Theorizing the effects of structural and organizational frames on in- dividual giving}

We argue that structural factors-including whether an organization works abroad and the domestic political environment of the group's host country-can serve as important heuristics in the decision to engage in philanthropy (Casale \& Baumann, 2015; Knowles \& Sullivan, 2017; Tremblay-Boire \& Prakash, 2017). We propose that the regulatory relationship between international NGOs and their host governments serves one such heuristic. NGO legislation is not inherently restrictive, and governments frequently use laws to regulate the behavior of NGOs (Bloodgood \& Tremblay-Boire, 2016; DeMattee, 2018). Restrictive NGO laws, on the other hand, are designed to limit organizational programming by imposing barriers to entry, funding, and advocacy (Spires, 2020). These stricter anti-NGO laws can signal to donors that governments perceive these groups as threatening and may crack down on them.

We argue that donors perceive legal crackdowns differently from organizationallevel heuristics-such as NGO missions and programming-because donors may be able to influence these latter attributes, at least to some extent. Conversely, donors can do little to change the domestic political environment of another country. Legal crackdowns abroad can signal to donors that the government may eventually target other NGOs as well, which can increase donor urgency to support legally besieged groups, even if donors are not completely satisfied with some organizational-level features of a group. As such, we expect that government restrictions abroad will increase respondents' likelihood of donating to the organization and increase the amount donated.

$\mathrm{H}_{\mathbf{1 a}}$ : If donors learn that NGOs face legal crackdowns abroad, then individual donors will be more likely to donate to them.

$\mathbf{H}_{\mathbf{i b}}$ : If donors learn that NGOs face legal crackdowns abroad, then individual donors will donate more to them.

Figure 1 represents this relationship formally. Legal crackdowns (C) have a direct effect on donor decisions ( $\mathrm{Y}$; donation likelihood and amount) because of their heuristic function. Legal crackdowns do not occur in isolation, however. Countries 


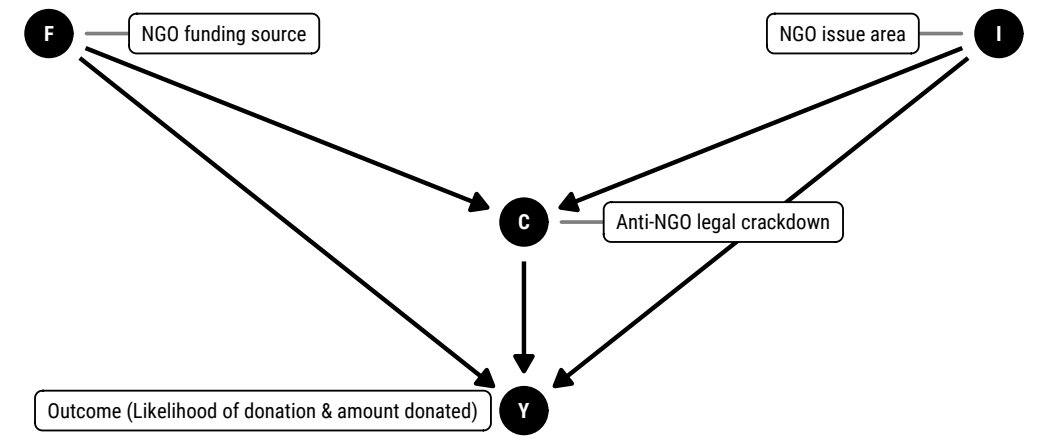

Figure 1: Causal diagram of the relationship of organizational and structural causes of donor preferences

are more likely to repress NGOs both when organizational issue areas (I) are in tension with government preferences and when organizations receive substantial funding (F) from abroad (Dupuy et al., 2015). Both of these organizational characteristics thus confound the causal effect of crackdowns on donor decisions and must be accounted for in the analysis-issue areas and funding sources simultaneously influence the likelihood of crackdown while also serving as organizational heuristics that influence donor preferences.

The contentiousness of NGO issue areas-or the degree to which an NGO's programming is compatible with government preferences, can also serve as an organizationlevel heuristic. ${ }^{5}$ NGOs that address humanitarian issues such as relief and development have broader appeal to donors and these issues rarely challenge the government. Further, their programmatic output is easily quantifiable and donors can see the results of their charity more readily (Bush, 2015). Previous research has shown that public donors do indeed differentiate between NGO issue areas, especially when these organizations are working in repressive contexts. Donor agencies in OECD countries respond to repressive NGO environments, especially those containing barriers to advocacy, by decreasing funds for groups working on politically sensitive causes such as anti-corruption initiatives, elections, human rights, legal reform and security sector reform, and instead increase funding for groups working on relatively tamer causes such as health, education and agriculture (Chaudhry \& Heiss, 2018).

Issue area contentiousness directly influences legal crackdowns, however, and confounds the heuristic effect of crackdowns on donor behavior (see Figure 1).

5. While anti-NGO legislation can theoretically target all NGOs within a state's borders, in practice these laws are enforced more selectively against contentious groups that pose threats to states (see Chaudhry, 2016; Heiss, 2017). 
NGOs working on more contentious human rights issues can be challenging to regimes (Heiss, 2017). These organizations are often viewed as politically motivated outsiders and run a higher risk of getting expelled (Dupuy et al., 2015), increasing the possibility of wasting donor resources. There is evidence that this a concern for private donors. In a survey of women's NGOs across the globe conducted by Mama Cash and Urgent Action Fund, many groups argued that private donors (especially foundations) were withdrawing from funding sensitive issues in repressive contexts, which in turn hurt women's and trans rights organizations. Some private funders, these groups argued, were also more likely to fund well-established groups that were more likely to survive crackdown (Bishop, 2017).

However, compared to our existing knowledge on public donors and foundation donors, we lack knowledge about how individuals respond to frames emphasizing one nonprofit issue area over another, especially a contentious area over a tamer one. NGOs working on tamer issues such as health, education, disaster relief, and humanitarian aid can often frame their activities as in need of greater support. This may strongly influence individual decisions to donate to relief efforts (Wiepking \& Bekkers, 2010). On the flip side, individual donors may believe that it is more difficult to improve human rights in the host country and subsequently shy away from donating to NGOs working on contentious causes.

As such, we hypothesize that donors will be more likely to donate to less contentious NGOs because these are seen as uncontroversial, apolitical, directed towards the most deserving of need, and are more capable of producing short-term quantifiable results. We use humanitarian NGOs as a proxy for groups working on non-contentious issues and human rights NGOs as a proxy for contentious issues.

$\mathbf{H}_{2 \mathrm{a}}$ : If donors learn that legally besieged NGOs work on humanitarian issues, then individual donors will be more likely to donate to them.

$\mathrm{H}_{2 \mathrm{~b}}$ : If donors learn that legally besieged NGOs work on humanitarian issues, then individual donors will donate more to them.

The final heuristic we examine is the source of NGO funding. Government grants to nonprofits can often crowd out private funding, though evidence is mixed on whether this completely or partially crowds out private dollars (Heutel, 2014; Steinberg, 1991). Donors may feel less inclined to contribute to NGOs receiving funds from agencies like the United States Agency for International Development (USAID) because such funding can signal a lack of independence from the government. Organizations that receive substantial funding from their home governments frequently avoid programming that would question the donor government even if such programming is in line with their mission (Stroup, 2012; Yu et al., 2020). In contrast, individual donors who see that organizations are privately funded may 
feel that they can also contribute and help and that their marginal donation would make a noticeable difference.

As funding restrictions are one of the most common forms of anti-NGO regulations (Dupuy et al., 2015), organizational funding again confounds the effect of anti-NGO crackdowns on donor behavior (see Figure 1). Accordingly, the combination of legal crackdown and funding may affect donor preferences. Individual donors may be less likely to donate to government-funded NGOs that face restrictions, since they may believe that legally besieged government-backed NGOs would enjoy the backing of their home government when facing difficulties. Legal trouble in the NGO's host country could also indicate mistrust between the home and host government-a dynamic that individuals may not wish to enter with their dollars. Donors thus may be likely to donate more to NGOs that rely on private funding.

$\mathrm{H}_{3 \mathrm{a}}$ : If donors learn that legally besieged NGOs receive substantial funding from their home government, then individual donors will be less likely to donate to them.

$\mathrm{H}_{3 \mathrm{~b}}$ : If donors learn that legally besieged NGOs receive substantial funding from their home government, then individual donors will donate less to them.

Importantly, when testing these hypotheses, we do not assume that individual donors have perfect knowledge about an NGO or the country an NGO operates in. Moreover, the average donor will not know exactly what "legal crackdown" entails for any given organization (i.e. does it mean an NGO was expelled, or that its assets were frozen, or that it received a fine?). For the sake of this experiment, this ambiguity is not a central concern as the heuristics we explore here are explicitly simplified shortcuts to donor information-gathering. Knowing that an organization works on human rights issues (even if donors are not familiar with specific kinds of rights), or knowing that an NGO faces legal trouble abroad should be enough to trigger the effect of these frames on donor preferences. Moreover, while many NGOs make information about their operations accessible through annual reports, it is time-consuming to track down that information. In each of these hypotheses, we assume that donors will not spend additional effort to research the exact details concerning crackdown, issue area, and funding sources. Instead, donors rely on signals and heuristics about the organization to shape their preferences and behavior (Szper \& Prakash, 2011).

We also posit that these signals work interactively to shape donor preferencesas seen in Figure 1, issue areas and funding sources each change the probability of NGO crackdown and confound causal relationships. As such, the effect of crackdown will be different depending on if an organization focuses on humanitarian 
assistance or human rights, or if it receives government funding or not. Accordingly, we test nested versions of these hypotheses in our analysis. it is unclear a priori what these interactive effects will be and which frames are more powerful when nested, though in general we expect the nested hypotheses to have an additive effect (i.e. because crackdown and humanitarian assistance should each have a positive effect on preferences on their own, the combination of the two will have a larger positive effect).

\section{Research design}

To measure the effect of structural and organization-level heuristics on individual donor preferences, we use an experiment to vary the different frames donors are exposed to. Comparing these effects allows us to measure the relative strength of these heuristics, and ultimately help NGOs tailor their fundraising strategies for individuals. Prior to launching the experiment, we preregistered our hypotheses and research design at the Open Science Framework, and our preregistration protocol is available at https://doi.org/10.17605/OSF.IO/DX973. The online appendix also includes the full text of the survey experiment, as well as details about our sample demographics, balance across experimental conditions, CONSORT diagram, and Bayesian priors. The analysis is fully reproducible using code and data available at https://doi.org/10.5281/zenodo.4058986 and https://dx.doi.org/10.17605/OSF. $\mathrm{IO} / \mathrm{FG}_{53} \mathrm{~W}$.

\section{Sample}

We test these hypotheses with a vignette-based survey experiment fielded through Amazon's Mechanical Turk. ${ }^{6}$ Our target population is the portion of Americans hypothetically willing to donate money for human rights and humanitarian work abroad. Our convenience sample (March 2018, N = 531) generally approximates the characteristics of our target population, since it is younger, more educated, wealthier, and more likely to donate to charities than nationally representative samples. Additionally, the majority of the sample $(\approx 90 \%)$ feels favorably toward human rights, humanitarian, and development NGOs.

6. Samples from Mechanical Turk are not nationally representative. However, because we targeted our study at people who are willing to donate online, we are not overly concerned with these discrepancies. Moreover, a growing body of research comparing Mechanical Turk with other sampling services finds it generally commensurable-see the online appendix for a lengthier discussion about this research. 


\section{Experimental treatments and outcomes}

We presented participants with a short paragraph with three manipulated frames, each highlighting different factors that might influence patterns of private philanthropy: (1) crackdown/no crackdown, (2) humanitarian assistance/human rights, and (3) government/private funding. We used the International Rescue Committee (IRC) as our example NGO because it fits within each possible frame and as such, requires no respondent deception. IRC provides humanitarian assistance and engages in human rights advocacy for refugees, more than a quarter of IRC's income comes from both government grants and private donations, and it works in countries with and without anti-NGO laws. ${ }^{7}$ We use a $2 \times 2 \times 2$ between-subject factorial design with participants randomly assigned to one of eight versions of the following vignette:

The International Rescue Committee (IRC) focuses on \{humanitarian assistance for refugees / human rights for refugees\} \{and works in countries that have recently passed laws that harshly restrict nonprofit organizations / NOTHING\}. A substantial proportion of IRC's funding comes from \{government / private\} donors.

We measured two outcomes: (1) how likely participants would be to donate to IRC (measured with a 5-point scale ranging from "Extremely likely" to "Extremely unlikely"), and (2) how much participants would hypothetically donate to IRC if they had an extra $\$ 100$. Research finds that the factors driving donation willingness and amounts differ depending on donor income, pro-social attitudes, self-image, and other psychological benefits (Wiepking, 2007). Accordingly, our framing treatments might differ across the two outcomes. We collapsed the likelihood scale into a binary variable measuring whether the participant is likely ("Extremely likely" and "Somewhat likely") or not likely (all other responses) to donate. ${ }^{8}$ We also included an exploratory free response question asking respondents to justify their choice.

Each of the varied treatments correspond to our hypotheses: crackdown vs. no crackdown, humanitarian assistance vs. human rights, and government vs. nongovernmental funding. Participants might misinterpret the vignette and assume that IRC's host governments fund the organization rather than its home government. In either case, knowing about government funding should still serve as a signal of the organization's deservingness. Similarly, there could be confusion with

7. Some respondents may have been influenced by prior opinions of IRC. Randomization distributes this bias across the different conditions and likely lessens the threat to validity.

8. An ordered probit model in the online appendix shows that results are consistent when using all five possible responses. 
phrase "private funding," but since we use it as the opposite of government funding, it should still act as a heuristic. Free responses tend to confirm the correct interpretation of the vignette, and many respondents explicitly justified their lack of support for IRC because of government funding, as expected ("I see that a large portion of its funding comes from government donors, so I feel it doesn't need me as much." $)$

\section{Estimation}

We test our first hypothesis by calculating the differences in the average likelihood to donate and the average amount donated across the crackdown conditions. For our second and third hypotheses we measure the difference in means spread across both issue and funding conditions. For additional exploration of the effect of issue and funding, we also measure the effect of crackdown within nested combinations of issue and funding conditions.

We use two Bayesian models to estimate the effect of crackdown on the likelihood of donating and the amount hypothetically donated. We model the proportion of respondents indicating they would likely donate as a binomial distribution:

$$
\begin{array}{rlrl}
n_{\text {group 1, group 2 }} & \sim \operatorname{Binomial}\left(n_{\text {group total }}, \theta_{\text {group }}\right) & \text { [likelihood] } \\
\Delta_{n} & =n_{\text {group 2 }}-n_{\text {group 1 }} & \text { [difference in proportions] } \\
n & : \text { Number likely to donate } & \\
\theta_{\text {group 1, group 2 }} & \sim \operatorname{Beta}(5,5) & & \text { [prior prob. of likelihood] }
\end{array}
$$

We estimate the mean amount donated in each condition using a $t$ distribution:

$$
\begin{aligned}
& x_{\text {group 1, group 2 }} \sim \text { Student } t(v, \mu, \sigma) \quad \text { [likelihood] } \\
& \Delta_{x}=x_{\text {group 2 }}-x_{\text {group 1 }} \quad \text { [difference in means] } \\
& x \text { : Mean amount donated } \\
& v \sim \text { Exponential(1/29) [prior normality] } \\
& \mu_{\text {group 1, group 2 }} \sim \mathcal{N}\left(\bar{x}_{\text {group 1, group 2 }}, 10\right) \quad \text { [prior donation mean per group] } \\
& \sigma_{\text {group 1, group 2 }} \sim \text { Cauchy }(0,1) \quad \text { [prior donation sd per group] }
\end{aligned}
$$

We use median values from the posterior distributions as point estimates and calculate credible intervals using the $95 \%$ highest posterior density. We declare an effect statistically significant if the posterior probability of being different from zero exceeds 0.95. Because differences can be either positive or negative (i.e. in some frames, the crackdown condition causes larger donations; in others it causes smaller donations), we report the probability that the difference is not equal to zero:

9. Response 6216778 . 
when the median value is negative we report the proportion of predicted values that are negative, and vice versa.

\section{Results}

Table 1 provides a summary of how our results map onto our hypotheses, both individually and nested within each other.

Table 1: Summary of hypotheses and results

\begin{tabular}{|c|c|c|c|}
\hline Hypothesis & Expectation & Results: Likelihood of donation & $\begin{array}{l}\text { Results: Amount } \\
\text { donated }\end{array}$ \\
\hline Crackdown & $\uparrow$ & No effect & Increase \\
\hline Humanitarian assistance & $\uparrow$ & No effect & No effect \\
\hline Government funding & $\downarrow$ & No effect & No effect \\
\hline \multicolumn{4}{|l|}{ Crackdown + issue area } \\
\hline $\begin{array}{l}\text { Crackdown }+ \\
\text { humanitarian assistance }\end{array}$ & $\begin{array}{l}\uparrow(\text { crackdown })+ \\
\uparrow(\text { humanitarian })\end{array}$ & Increase & Increase \\
\hline $\begin{array}{l}\text { Crackdown + } \\
\text { human rights }\end{array}$ & $\begin{array}{l}\uparrow(\text { crackdown) + } \\
\downarrow \text { (human rights) }\end{array}$ & No effect & No effect \\
\hline \multicolumn{4}{|l|}{ Crackdown + funding } \\
\hline $\begin{array}{l}\text { Crackdown + } \\
\text { government funding }\end{array}$ & $\begin{array}{l}\uparrow(\text { crackdown })+ \\
\downarrow \text { (government) }\end{array}$ & No effect & No effect \\
\hline $\begin{array}{l}\text { Crackdown }+ \\
\text { private funding }\end{array}$ & $\begin{array}{l}\uparrow(\text { crackdown })+ \\
\uparrow(\text { private })\end{array}$ & Increase & Increase \\
\hline \multicolumn{4}{|l|}{ Crackdown + issue + funding } \\
\hline $\begin{array}{l}\text { Crackdown + } \\
\text { humanitarian assistance }+ \\
\text { government funding }\end{array}$ & $\begin{array}{l}\uparrow(\text { crackdown })+ \\
\uparrow(\text { humanitarian })+ \\
\downarrow \text { (government) }\end{array}$ & No effect & Increase \\
\hline $\begin{array}{l}\text { Crackdown }+ \\
\text { humanitarian assistance }+ \\
\text { private funding }\end{array}$ & $\begin{array}{l}\uparrow(\text { crackdown })+ \\
\uparrow(\text { humanitarian })+ \\
\uparrow(\text { private })\end{array}$ & No effect & No effect \\
\hline $\begin{array}{l}\text { Crackdown + } \\
\text { human rights }+ \\
\text { government funding }\end{array}$ & $\begin{array}{l}\uparrow(\text { crackdown })+ \\
\downarrow \text { (human rights })+ \\
\downarrow \text { (government) }\end{array}$ & Decrease & Decrease \\
\hline $\begin{array}{l}\text { Crackdown }+ \\
\text { human rights }+ \\
\text { private funding }\end{array}$ & $\begin{array}{l}\uparrow(\text { crackdown })+ \\
\downarrow \text { (human rights })+ \\
\uparrow(\text { private })\end{array}$ & Increase & Increase \\
\hline
\end{tabular}

\section{Likelihood of donation}

In isolation we find that respondents are not more likely to donate to legally besieged INGOs $\left(\mathrm{H}_{1 \mathrm{a}}\right)$. As seen in Figure $2(\mathrm{~A})$, those exposed to the crackdown con- 
dition tend to have a slightly higher probability of donating $(46.7 \%)$ than those in the control condition (42.9\%), but the difference is not significant $(\Delta=3.8 \%$; $p(\Delta \neq 0)=0.82)$. We find similar results when looking at the isolated effects of issue area and funding. Both differences are positive, but the posterior probability of being larger than zero is low $\left(\Delta_{\text {issue }}=2.3 \% ; p\left(\Delta_{\text {issue }} \neq 0\right)=0.7 ; \Delta_{\text {funding }}=2.9 \%\right.$; $\left.p\left(\Delta_{\text {funding }} \neq 0\right)=0.75\right)$. We thus do not initially find evidence that crackdowns (or issue or funding) alone increase the likelihood of donating.

Table 2: Likelihood of donation and differences in proportions in "crackdown" (treatment) and "no crackdown" (control) conditions; values represent posterior medians

\begin{tabular}{|c|c|c|c|c|c|}
\hline $\mathrm{H}_{1 \mathrm{a}}$ & $\%$ likely $_{\text {Treatment }}$ & $\%$ likely $_{\text {Control }}$ & $\Delta$ & $\% \Delta$ & $p(\Delta \neq 0)$ \\
\hline Crackdown - No crackdown & $46.7 \%$ & $42.9 \%$ & $3.8 \%$ & $8.9 \%$ & 0.82 \\
\hline $\begin{array}{l}\text { Humanitarian assistance - Human } \\
\text { rights }\end{array}$ & $45.9 \%$ & $43.7 \%$ & $2.3 \%$ & $5.4 \%$ & 0.7 \\
\hline Private - Government funding & $46.3 \%$ & $43.4 \%$ & $2.9 \%$ & $6.8 \%$ & 0.75 \\
\hline $\mathrm{H}_{2 \mathrm{a}}$ and $\mathrm{H}_{3 \mathrm{a}}$ & $\begin{array}{c}\% \\
\text { likely } \\
\text { Crackdown }\end{array}$ & $\%$ likely $_{\text {No crackdown }}$ & $\Delta$ & $\% \Delta$ & $p(\Delta \neq 0)$ \\
\hline Human rights issues & $44.3 \%$ & $43.6 \%$ & $0.6 \%$ & $1.5 \%$ & 0.54 \\
\hline Humanitarian assistance issues & $49.4 \%$ & $42.5 \%$ & $6.8 \%$ & $15.9 \%$ & 0.88 \\
\hline Government funding & $41.3 \%$ & $45.8 \%$ & $-4.6 \%$ & $-10.0 \%$ & 0.78 \\
\hline Private funding & $52.4 \%$ & $40.3 \%$ & $12.1 \%$ & $30.2 \%$ & 0.98 \\
\hline $\mathrm{H}_{2 \mathrm{a}}$ and $\mathrm{H}_{3 \mathrm{a}}$ (nested) & $\frac{\%}{\text { likely }_{\text {Crackdown }}}$ & $\%$ likely $_{\text {No crackdown }}$ & $\Delta$ & $\% \Delta$ & $p(\Delta \neq 0)$ \\
\hline $\begin{array}{l}\text { Human rights issues, Government } \\
\text { funding }\end{array}$ & $32.0 \%$ & $47.4 \%$ & $-15.4 \%$ & $-32.5 \%$ & 0.97 \\
\hline Human rights issues, Private funding & $57.4 \%$ & $40.4 \%$ & $16.9 \%$ & $41.5 \%$ & 0.98 \\
\hline $\begin{array}{l}\text { Humanitarian assistance issues, } \\
\text { Government funding }\end{array}$ & $51.4 \%$ & $44.7 \%$ & $6.8 \%$ & $15.2 \%$ & 0.8 \\
\hline $\begin{array}{l}\text { Humanitarian assistance issues, } \\
\text { Private funding }\end{array}$ & $47.5 \%$ & $41.2 \%$ & $6.1 \%$ & $14.8 \%$ & 0.78 \\
\hline
\end{tabular}

Figure $2(\mathrm{~B}-\mathrm{C})$ shows the difference in the likelihood of donation for both crackdown conditions across NGO issue areas $\left(\mathrm{H}_{2 \mathrm{a}}\right)$ and funding sources $\left(\mathrm{H}_{3 \mathrm{a}}\right)$. Crackdown has almost no effect on the likelihood of donating to human rights NGOs $(p(\Delta \neq 0)=0.54)$, which is not surprising, since people who donate to these kinds of NGOs likely know that their work is challenging to host governments. We hypothesized that the positive crackdown effect would be stronger for humanitarian NGOs, and while crackdown does have a positive effect under the humanitarian frame, the probability this difference is greater than zero is below our $95 \%$ threshold $(p(\Delta \neq 0)=0.88)$.

We do find some evidence for $\mathrm{H}_{3 \mathrm{a}}$, however. Crackdown has little effect on individual preferences to donate to NGOs receiving government funding ( $p(\Delta \neq$ $0)=0.78)$, but it does increase the likelihood of donating to privately funded NGOs by $30 \%(\Delta=12.1 \% ; p(\Delta \neq 0)=0.98)$. This is likely because a donor might feel that their marginal donation would make a difference. For instance, one respondent 
A

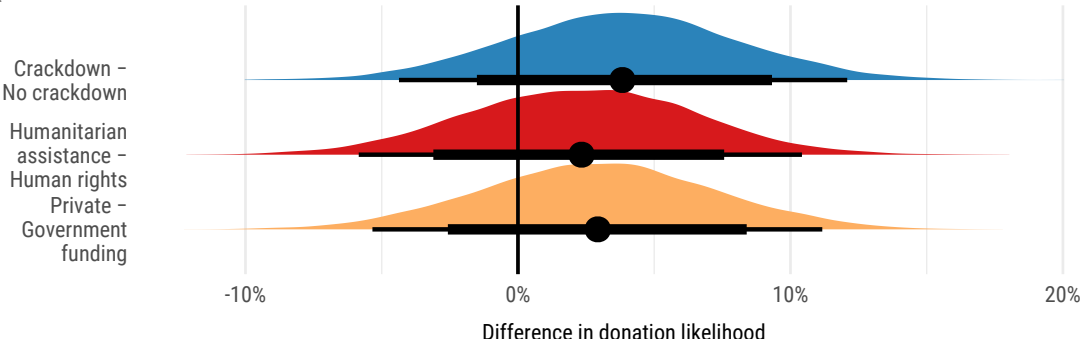

B

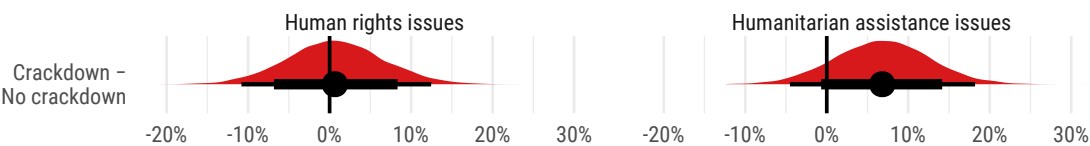

Crackdown No crackdown

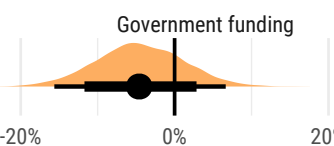

$20 \%$

$-20 \%$

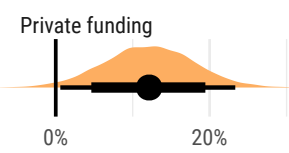

Difference in donation likelihood
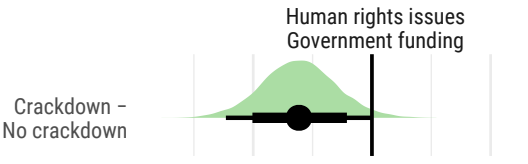

Human rights issues No crackdown

Humanitarian assistance issues

Crackdown No crackdown
Government funding

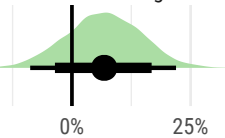

$25 \% \quad 50 \%$

Difference in donation likelihood
Private funding

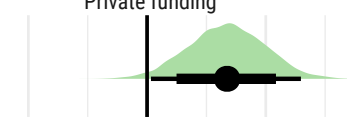

Humanitarian assistance issues

$$
\text { Private funding }
$$

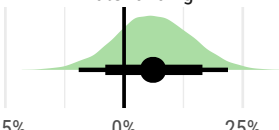

$50 \%$

Point shows posterior median; thick black lines show $80 \%$ credible interval; thin black lines show $95 \%$ credible interval

Figure 2: Difference in likelihood of donation across crackdown and no crackdown groups, conditioned by other experimental frames 
reasoned that since IRC "is already receiving funding from governments, so funding from private individuals doesn't seem as necessary. I'd prefer to give my money to an organization that is primarily run by private donations." 10

While the crackdown frame has no effect on the probability of donating to human rights NGOs alone, conditioning this finding on the source of NGO funding reveals competing trends. Figure 2(D) shows the difference in donation likelihood across all experimental conditions. When donors know that a human rights organization is primarily government-funded, they are substantially less likely to donate if the organization faces government crackdown abroad. This follows our expected hypotheses for both issue area and funding $(\Delta=-15.4 \% ; p(\Delta \neq 0)=$ 0.97). This finding possibly reflects donor suspicion about the mission and goals of government-funded human rights programming. For instance, one respondent in the government and human rights conditions explained that they did not donate because "government donors might have interests that actually hurt refugees, and are donating to have some sway in the organization"11

In contrast, when donors know that a human rights organization is privately funded, they are more likely to donate when there is a legal crackdown than when the NGO faces no legal hurdles $(\Delta=16.9 \% ; p(\Delta \neq 0)=0.98)$. As explained previously, each of the heuristics on their own influence the propensity to donate, but we do not yet know how the interaction between heuristics affects donor behavior. Here, the private funding heuristic appears to override the dampening in likelihood that should come from focusing on more contentious human rights issues. For humanitarian assistance NGOs, however, legal crackdowns do not have a significant effect on the likelihood of donation when nesting either funding or issue framesneither of the nested experimental frames play a heuristic role.

These results give partial support to $\mathrm{H}_{3 \mathrm{a}}$. The source of funding has little influence on the preference to donate to humanitarian NGOs, but on average, donors are substantially more likely to want to give to privately funded human rights NGOs than government-funded organizations. Additionally donors appear to both punish government-funded human rights NGOs facing crackdown and rally behind privately funded NGOs facing those same hurdles. For instance, one respondent who was presented with a government-funded human rights version of IRC explained that "I'm not exactly sure what they did was right or wrong, I think it just seems bad, so I'm less likely to want to donate to them." ${ }^{2}$ Other respondents showed increased support when presented with a privately-funded version of IRC, explaining that they would donate a substantial amount because "[ $t$ ]hey [IRC] are doing

10. Response 6486084 .

11. Response 2560169 .

12. Response 8425616 . 
good work in countries where it is tough for groups like them to operate and they need all the help they can get." ${ }^{\prime 3}$ Individual donors thus seem to be more willing to support besieged human rights organizations when they are unencumbered by government funds.

\section{Amount donated}

On their own, crackdowns do not substantially influence donors' likelihood to donate, but they do increase the amount of money that respondents are willing to contribute (see Figure 3(A)). Informing participants that IRC faces legal hurdles abroad increased donations by $\$ 3.39$ on average, a $26 \%$ increase from the no crackdown condition $(p(\Delta \neq 0)=0.97)$. This provides good evidence for $\mathrm{H}_{1 b}$-donors appear to give more money to besieged INGOs. In contrast, neither issue area nor funding on their own have an effect on the amount donated $\left(\Delta_{\text {issue }}=-0.78\right.$; $\left.p\left(\Delta_{\text {issue }} \neq 0\right)=0.66 ; \Delta_{\text {funding }}=1.44 ; p\left(\Delta_{\text {funding }} \neq 0\right)=0.78\right)$.

Table 3: Mean values and differences in means for amount donated in "crackdown" (treatment) and "no crackdown" (control) conditions; values represent posterior medians

\begin{tabular}{|c|c|c|c|c|c|}
\hline $\mathrm{H}_{1 \mathrm{~b}}$ & Amount $_{\text {Treatment }}$ & Amount $_{\text {Control }}$ & $\Delta$ & $\% \Delta$ & $p(\Delta \neq 0)$ \\
\hline Crackdown - No crackdown & 16.35 & 12.96 & 3.39 & $26.3 \%$ & 0.97 \\
\hline $\begin{array}{l}\text { Humanitarian assistance - Human } \\
\text { rights }\end{array}$ & 14.01 & 14.84 & -0.78 & $-5.3 \%$ & 0.66 \\
\hline Private - Government funding & 15.11 & 13.65 & 1.44 & $10.6 \%$ & 0.78 \\
\hline $\mathrm{H}_{2 \mathrm{~b}}$ and $\mathrm{H}_{3 \mathrm{~b}}$ & Amount $_{\text {Crackdown }}$ & Amount $_{\text {No crackdown }}$ & $\Delta$ & $\% \Delta$ & $p(\Delta \neq 0)$ \\
\hline Human rights issues & 17.43 & 14.94 & 2.49 & $16.8 \%$ & 0.83 \\
\hline Humanitarian assistance issues & 16.01 & 11.74 & 4.27 & $36.5 \%$ & 0.96 \\
\hline Government funding & 13.87 & 12.26 & 1.64 & $13.5 \%$ & 0.74 \\
\hline Private funding & 18.97 & 14.33 & 4.55 & $31.6 \%$ & 0.96 \\
\hline $\mathrm{H}_{2 \mathrm{~b}}$ and $\mathrm{H}_{3 \mathrm{~b}}$ (nested) & Amount $_{\text {Crackdown }}$ & Amount $_{\text {No crackdown }}$ & $\Delta$ & $\% \Delta$ & $p(\Delta \neq 0)$ \\
\hline $\begin{array}{l}\text { Human rights issues, Government } \\
\text { funding }\end{array}$ & 10.55 & 15.04 & -4.49 & $-29.9 \%$ & 0.9 \\
\hline Human rights issues, Private funding & 23.71 & 14.5 & 9.09 & $62.7 \%$ & 0.99 \\
\hline $\begin{array}{l}\text { Humanitarian assistance issues, } \\
\text { Government funding }\end{array}$ & 21.42 & 11.97 & 9.18 & $76.4 \%$ & 0.99 \\
\hline $\begin{array}{l}\text { Humanitarian assistance issues, } \\
\text { Private funding }\end{array}$ & 15.73 & 15.79 & -0.03 & $-0.2 \%$ & 0.5 \\
\hline
\end{tabular}

This trend also holds when nesting crackdown within NGO issue area. The crackdown condition elicits higher donations for both the human rights and humanitarian NGOs, though with varying levels of significance (see Figure $3(\mathrm{~B}-\mathrm{C})$ ). Emphasizing legal crackdown increases donations to human rights NGOs by $\$ 2.49$, but with a lower probability of significance $(p(\Delta \neq 0)=0.83)$. In contrast, crackdowns boost donations to humanitarian NGOs by $\$ 4.27$, a $37 \%$ increase beyond the control condition $(p(\Delta \neq 0)=0.96)$. We thus find support for $\mathrm{H}_{2 \mathrm{~b}}$ : donors give

13. Response 3025921. 
A

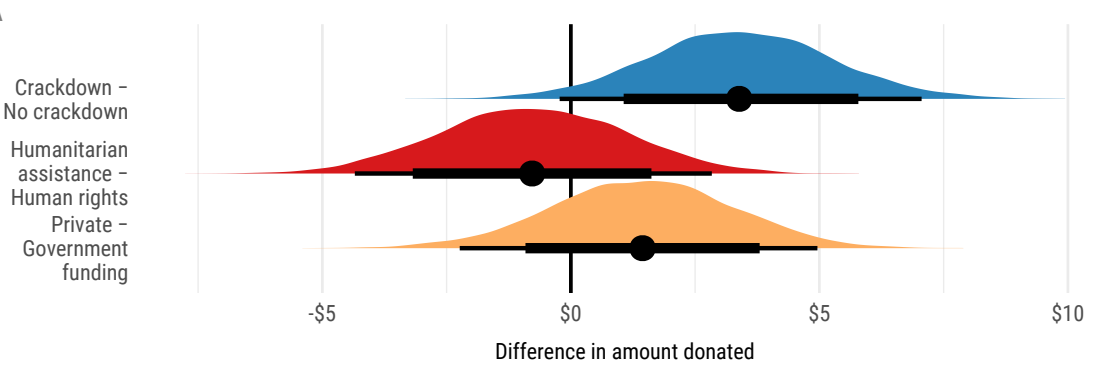

B

Crackdown -
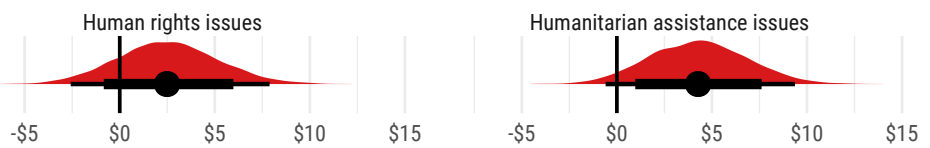

C

Crackdown No crackdown
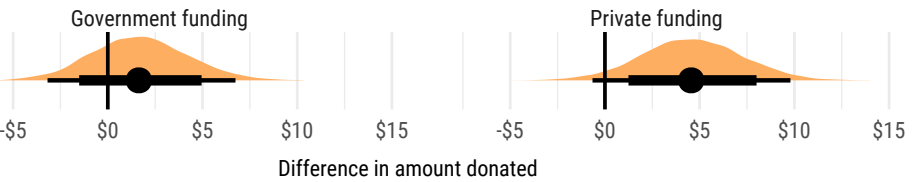

D

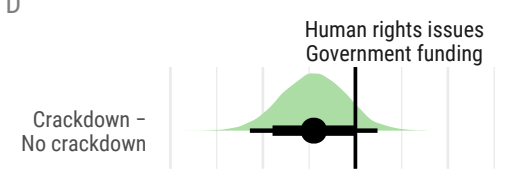

Humanitarian assistance issues Government funding

Crackdown No crackdown $-\$ 20$

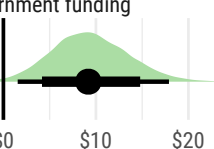

Difference in amount donated

Point shows posterior median; thick black lines show $80 \%$ credible interval thin black lines show $95 \%$ credible interval

Figure 3: Difference in amount donated across crackdown and no crackdown groups, conditioned by other experimental frames 
more to besieged humanitarian NGOs. We also find evidence for $\mathrm{H}_{3 \mathrm{~b}}$. Donors give $\$ 4.55$ more (a $32 \%$ increase) to legally besieged NGOs that are privately funded, as hypothesized, $(p(\Delta \neq 0)=0.96)$. However, the crackdown condition has little effect on the amount donated to government-funded NGOs $(p(\Delta \neq 0)=0.74)$. This is possibly because the effects cancel each other out-legal crackdowns should increase the amount donated, but reliance on government funding dissuades donors from giving, as predicted by the literature showing that governments can crowd out private funding.

Combining issue areas and funding sources provides more texture. We previously found that donors are less likely to donate to government-funded human rights NGOs and more likely to donate to privately funded human rights NGOs when they face legal issues. These trends also apply to preferences in the amount donors donate. Respondents were willing to donate $\$ 9.09$ more to besieged privately funded human rights NGOs compared to the no crackdown control condition $(p(\Delta \neq 0)=0.99)$, increasing their donations by $63 \%$. Respondents explained that they chose to give additional money to privately funded human rights NGOs precisely because "the country limits non-profits." ${ }^{4}$ The punishment mechanism found previously does not translate to the amount donated-while there is a decrease of $\$ 4.49$ in average donations to government-funded human rights NGOs facing crackdown, the chance this difference is less than zero is lower than our threshold $(p(\Delta \neq 0)=0.9)$.

Emphasizing legal difficulties increased donations to government-funded humanitarian NGOs by $76 \%$, or $\$ 9.18(p(\Delta \neq 0)=0.99)$. The crackdown condition causes this increase despite some hesitation from respondents who often indicated that government-funded NGOs do not deserve private donations. Many respondents in the crackdown condition argued that " $[\mathrm{m}] \mathrm{y}$ tax paying dollars go to the government and if the government is helping to fund it then they are in turn getting some of my money." ${ }^{15}$ This hesitation is not universal, however, and in aggregate most respondents chose to give substantially more. Many echoed this respondent, who identified the crackdown condition as one of the reasons for giving the full hypothetical \$100: "If they can function without being affected by the harsh laws against non-profits, I would want them to have as much help as possible to do their humanitarian work." ${ }^{16}$ Thus, legal crackdowns can increase individual donor urgency to support an organization, and this heuristic is potentially processed differently compared to other organization-level heuristics or information from social networks.

14. Response 13685 .

15. Response 9509936.

16. Response 1097165 . 
In contrast, crackdowns have no substantial effect on the amount donated to privately funded humanitarian NGOs $(p(\Delta \neq 0)=0.5)$. No respondent in these conditions mentioned funding sources in their justification, and many explained that they would not give solely because of the crackdown and that they "would keep all $\$ 100$ because it would not even go to helping humanitarian efforts due to the new laws." ${ }^{17}$ It is thus possible that donors see government-funded humanitarian NGOs as more legitimate and more capable of handling difficult legal restrictions than privately funded organizations. Donors might assume that an NGO that receives government funding would have support from the home government when facing legal challenges, while an NGO funded by small donors would be less able to confront such challenges. Further research is needed to probe this trend.

\section{Discussion: Can these preferences translate to behavior?}

While the survey experiment allows us to hold the organization constant and test for specific hypotheses, there are a few caveats to consider when interpreting these results and applying them to nonprofit fundraising. This is because the experiment measures preferences (willingness to donate) rather than behavior (actual donations). However, there is evidence that individuals' willingness to donate (as measured in the experiment) translates well into behavior. The wording of the survey experiment uses an informational frame, where the focus is on educating respondents. This is in stark contrast to the use of personal frames, which draw the audience's attention to the plight of an individual, or motivational frames, which are meant to motivate individuals to act by creating feels of agency and efficacy. ${ }^{18}$ Prior research has shown that informational frames are the most important frames in generating donations (McEntire et al., 2015).

Moreover, informational frames are a necessary precondition for encouraging action in human rights nonprofit campaigns, and individuals are more likely to donate when informational frames are combined with personal frames (McEntire et al., 2015). Our experiment shows a substantial increase in donors' willingness to donate to human rights groups facing crackdown, especially those that are privatelyfunded, and this result emerges from the use of only informational frames. If organizations combined with information with personal frames, research suggests these donations may further increase.

It is also worth noting that there is evidence, at least domestically, that restrictions on nonprofit activities spur changes in private donors' giving patterns. For in-

17. Response 8995923.

18. Personal frames humanize victims and entice action by invoking an emotional reaction. Prior research finds that people are more be generous when donating to a campaign with a single victim, rather than a statistical group of victims (Slovic, 2007). 
stance, after Texas and other states pledged to impose new restrictions on Planned Parenthood following the 2016 election, donations to the organization increased more than 40 times the usual amount (Cooney, 2016). Thus, donor preferences of increased generosity towards legally besieged groups abroad also has some domestic parallels.

\section{Conclusion}

In the era of closing civic space, dozens of countries restricted international NGO funding and programming. With the consequent withdrawal of official governmental aid, many INGOs have turned to foreign individual donors as an additional funding source. Since seeking out perfect information about a nonprofit and its activities-especially international programming-is costly and time-consuming, donors use heuristics when deciding which organizations to support. In this paper, we argue that informational heuristics about NGOs' legal environments and organizational-level attributes can influence donor preferences for international giving.

Using a survey experiment with respondents in the U.S., we find that the domestic political environments of INGO host countries can serve as one such signal. Our results show that while crackdowns do not consistently influence individual preferences of donation on their own, respondents indicated willingness to donate $26 \%$ more to legally restricted NGOs. This effect persists when mediated by other organizational heuristics, with respondents giving $37 \%$ more to humanitarian NGOs, and $63 \%$ more to privately funded human rights NGOs.

This article should be viewed as an exploratory study. While the survey experiment allows us to hold the organization constant and test for specific hypotheses, there are limits to its external validity. Our sample captures people who are relatively more likely to donate to charities and thus does not reflect the general U.S. population. Our findings do not apply to the total population-we still know very little about how anti-NGO crackdowns change perceptions of nonprofits in general.

Future research should test the generalizability of our findings to individual donors in other countries, as well as determine the extent to which these preferences translate into behavior. For instance, the nonprofit sector in the U.S. relies more heavily on government funding than in Europe. In the latter, large organizations like Amnesty International and Médecins Sans Frontières receive very little support from their home governments (Stroup, 2012). This may imply that donors in European countries will have different preferences when choosing to donate to government and privately-funded organizations. Future research should also look more narrowly at donors who regularly give to international causes, as these 
individuals are likely more aware of political trends in the countries where their preferred organizations work.

Because our sample reflects those who are already willing to donate to charities, these results have important implications for nonprofit fundraising. NGOs may benefit from publicizing when they are targets of government crackdown and including that information in their framing appeals. While this may not be enough to sway the average U.S. donor, our results show that communicating this information can convince already-likely donors to donate more to besieged groups. Further, if NGOs signal to donors that they receive a majority of their funding from private sources, they may be able to convince individual donors that their contributions might help the NGO resist the crackdown.

\section{References}

Bekkers, R. (2010). Who gives what and when? A scenario study of intentions to give time and money. Social Science Research, 39(3), 369-381. https://doi.org/10.1016/j.ssresearch.2009.08.008

Bekkers, R., \& Wiepking, P. (2011). A literature review of empirical studies of philanthropy: Eight mechanisms that drive charitable giving. Nonprofit and Voluntary Sector Quarterly, 40(5), 924973. https://doi.org/10.1177/0899764010380927

Bermeo, S. B. (2011). Foreign aid and regime change: A role for donor intent. World Development, 39(11), 2021-2031. https://doi.org/10.1016/j.worlddev.2011.07.019

Bishop, K. (2017). Standing firm: Women and trans-led organisations respond to closing civic space for civil society. Mama Cash and Urgent Action Fund.

Bloodgood, E., \& Tremblay-Boire, J. (2016). Does government funding depoliticize non-governmental organizations? Examining evidence from Europe. European Political Science Review, 9(3), 401-424. https://doi.org/10.1017/S1755773915000430

Brechenmacher, S. (2017). Civil society under assault: Repression and response in Russia, Egypt, and Ethiopia. Washington, D. C., Carnegie Endowment for International Peace. http://carnegieendowment. $\mathrm{org} / 2017 / 05 / 18 /$ civil- society- under-assault-repression- and-responses-in-russia- egypt-andethiopia-pub-69953

Bush, S. S. (2015). The taming of democracy assistance: Why democracy promotion does not confront dictators. Cambridge, UK, Cambridge University Press. https://doi.org/10.1017/cbo9781107706934

Carothers, T. (2015). The closing space challenge: How are funders responding? Washington, D. C., Carnegie Endowment for International Peace.

Casale, D., \& Baumann, A. (2015). Who gives to international causes? A sociodemographic analysis of US donors. Nonprofit and Voluntary Sector Quarterly, 44(1), 98-122. https:// doi.org/10.1177/ o899764013507141

Chaudhry, S. (2016). The assault on democracy assistance: Explaining state repression of NGOs (Doctoral dissertation). Yale University. New Haven, Connecticut.

Chaudhry, S., \& Heiss, A. (2018). Are funders really responding? Analyzing the impact of global restrictions on NGOs [Working paper]. Working paper.

Chong, D., \& Druckman, J. N. (2007). Framing theory. Annual Review of Political Science, 10, 103-126. https://doi.org/10.1146/annurev.polisci.10.072805.103054

Cooney, S. (2016). Planned Parenthood has received 30o,ooo donations since the election [magazine]. Time. https://time.com/4618359/planned-parenthood-election-donations/ 
Croson, R., \& Shang, J. (2011). How social norms, price, and scrutiny influence donation behavior: Evidence from four natural field experiments. In D. M. Oppenheimer \& C. Y. Olivola (Eds.), The science of giving: Experimental approaches to the study of charity (pp. 65-80). New York, Taylor \& Francis.

DeMattee, A. J. (2018). Toward a coherent framework: A typology and conceptualization of CSO regulatory regimes. Nonprofit Policy Forum, 9(4), 1-17. https://doi.org/10.1515/npf-2018-0011

Desai, R. M., \& Kharas, H. (2018). What motivates private foreign aid? Evidence from internet-based microlending. International Studies Quarterly, 62(3), 505-519. https://doi.org/10.1093/isq/sqyo23

Development Initiatives. (2020). Global humanitarian assistance report 2020. https:// devinit.org/ resources/global-humanitarian-assistance-report-2020/international-humanitarian-assistance/

Dietrich, S. (2013). Bypass or engage? Explaining donor delivery tactics in foreign aid allocation. International Studies Quarterly, 57(4), 698-712. https://doi.org/10.1111/isqu.12041

Dietrich, S., \& Wright, J. (2015). Foreign aid allocation tactics and democratic change in Africa. fournal of Politics, 77(1), 216-234. https://doi.org/10.1086/678976

Dupuy, K., \& Prakash, A. (2018). Do donors reduce bilateral aid to countries with restrictive NGO laws? A panel study, 1993-2012. Nonprofit and Voluntary Sector Quarterly, 47(1), 89-106. https: //doi.org/10.1177/0899764017737384

Dupuy, K., Ron, J., \& Prakash, A. (2015). Who survived? Ethiopia's regulatory crackdown on foreignfunded NGOs. Review of International Political Economy, 22(2), 419-56. https://doi.org/10.1080/ 09692290.2014.903854

Dupuy, K., Ron, J., \& Prakash, A. (2016). Hands off my regime! governments' restrictions on foreign aid to non-governmental organizations in poor and middle-income countries. World Development, 84, 299-311. https://doi.org/10.1016/j.worlddev.2016.02.001

Fengler, W., \& Kharas, H. (2010). Overview: Delivering aid differently. In Delivering aid differently: Lessons from the field (pp. 1-41). Washington, D. C., Brookings Institution Press.

Foundation Center. (2018). The state of global giving by U.S. foundations: 2011-2015. New York. https: //www.issuelab.org/resources/31306/31306.pdf

Giving USA. (2017, June 12). Total charitable donations rise to new high of \$39o.o5 billion. https:// givingusa.org/giving-usa-2017-total-charitable-donations-rise-to-new-high-of-39o-o5-billion/

Giving USA. (2019). Giving USA 2019: Americans gave $\$ 427.71$ billion to charity in 2018 amid complex year for charitable giving. https:// givingusa. org/giving - usa - 2019- americans - gave - 427- 71billion-to-charity-in-2018-amid-complex-year-for-charitable-giving/

Heiss, A. (2017). Amicable contempt: The strategic balance between dictators and international NGOs (Doctoral dissertation). Duke University. Durham, NC.

Herzog, P. S., \& Yang, S. (2018). Social networks and charitable giving: Trusting, doing, asking, and alter primacy. Nonprofit and Voluntary Sector Quarterly, 47(2), 376-394. https://doi.org/10.1177/ 0899764017746021

Heutel, G. (2014). Crowding out and crowding in of private donations and government grants. Public Finance Review, 42(2), 143-175. https://doi.org/10.1177/1091142112447525

Hossain, B., \& Lamb, L. (2017). Associational capital and adult charitable giving: A Canadian examination. Nonprofit and Voluntary Sector Quarterly, 46(5), 963-983. https:// doi.org/10.1177/ o899764017703707

IUPUI Lilly Family School of Philanthropy. (2017). Giving USA 2017: The annual report on philanthropy for the year 2016.

Knowles, S., \& Sullivan, T. (2017). Does charity begin at home or overseas? Nonprofit and Voluntary Sector Quarterly, 46(5), 944-62. https://doi.org/10.1177/0899764017703710

McEntire, K. J., Leiby, M., \& Krain, M. (2015). Human rights organizations as agents of change: An experimental examination of framing and micromobilization. American Political Science Review, 109(3), 407-426. https://doi.org/10.1017/sooo3055415000295 
Micklewright, J., \& Schnepf, S. V. (2009). Who gives for overseas development? Journal of Social Policy, 38(2), 317-41. https://doi.org/10.1017/soo47279408002869

Milner, H. V., \& Tingley, D. H. (2010). The political economy of US foreign aid: American legislators and the domestic politics of aid. Economics \& Politics, 22(2), 200-232. https://doi.org/10.1111/j.14680343.2009.00356.x

Norris, J. (2019). Special feature: A history of American public opinion on foreign aid. Devex. https: //www.devex.com/news/special-feature-a-history-of-american-public-opinion-on-foreign-aid90732

Rajan, S. S., Pink, G. H., \& Dow, W. H. (2009). Sociodemographic and personality characteristics of Canadian donors contributing to international charity. Nonprofit and Voluntary Sector Quarterly, 38(3), 413-40. https://doi.org/10.1177/0899764008316056

Ryazanov, A. A., \& Christenfeld, N. J. (2018). On the limited role of efficiency in charitable giving. Nonprofit and Voluntary Sector Quarterly, 47(5), 939-959. https://doi.org/10.1177/0899764018773899

Sloan, M. F. (2009). The effects of nonprofit accountability ratings on donor behavior. Nonprofit and Voluntary Sector Quarterly, 38(2), 220-36. https://doi.org/10.1177/0899764008316470

Slovic, P. (2007). "If I look at the mass I will never act": Psychic numbing and genocide. fudgment and Decision Making, 2(2), 79-95.

Spires, A. J. (2020). Regulation as political control: China's first charity law and its implications for civil society. Nonprofit and Voluntary Sector Quarterly, 49(3), 571-588. https:// doi.org/10.1177/ o899764019883939

Steinberg, R. (1991). Does government spending crowd out donations? Annals of Public and Cooperative Economics, 62(4), 591-612. https://doi.org/10.1111/j.1467-8292.1991.tbo1369.x

Stroup, S. S. (2012). Borders among activists: International NGOs in the United States, Britain, and France. Ithaca, New York, Cornell University Press. https://doi.org/10.7591/9780801464256

Szper, R., \& Prakash, A. (2011). Charity watchdogs and the limits of information-based regulation. Voluntas: International fournal of Voluntary and Nonprofit Organizations, 22(1), 112-41. https://doi. org/10.1007/s11266-010-9156-2

Tremblay-Boire, J., \& Prakash, A. (2017). Will you trust me?: How individual American donors respond to informational signals regarding local and global humanitarian charities. Voluntas: International fournal of Voluntary and Nonprofit Organizations, 28(2), 621-47. https://doi.org/10.1007/s11266016-9782-4

US Trust. (2014). High net worth philanthropy. Indianapolis, IN, US Trust; the Lilly Family School of Philanthropy.

Wiepking, P. (2007). The philanthropic poor: In search of explanations for the relative generosity of lower income households. Voluntas: International fournal of Voluntary and Nonprofit Organizations, 18(4), 339-358. https://doi.org/10.1007/s11266-007-9049-1

Wiepking, P. (2010). Democrats support international relief and the upper class donates to art? How opportunity, incentives and confidence affect donations to different types of charitable organizations. Social Science Research, 39(6), 1073-87. https://doi.org/10.1016/j.ssresearch.2010.06.005

Wiepking, P., \& Bekkers, R. (2010). Does who decides really matter? Causes and consequences of personal financial management in the case of larger and structural charitable donations. Voluntas: International fournal of Voluntary and Nonprofit Organizations, 21(2), 240-263. https://doi.org/10. 1007/s11266-010-9124-X

Wiepking, P., \& Maas, I. (2009). Resources that make you generous: Effects of social and human resources on charitable giving. Social Forces, 87(4), 1973-1995. https://doi.org/10.1353/sof.o.0191

Yu, J., Shen, Y., \& Li, Y. (2020). Understanding the effect of central government funding on the service and advocacy roles of nonprofit organizations in China: A cross-regional comparison. Nonprofit and Voluntary Sector Quarterly. https://doi.org/10.1177/0899764019892085 